\title{
School Leaders' Resilience amidst Pandemic in the Division of Laguna, Philippines
}

\author{
Nilda V. San Miguel ${ }^{\mathrm{a}}$, Elymar A. Pascual ${ }^{\mathrm{b}}$ \\ elymarpascual@rocketmail.com \\ ${ }^{a}$ Department of Education, Lumban, Laguna, Philippines, 4014 \\ ${ }^{\mathrm{b}}$ Department of Education, Nagcarlan, Laguna, Philippines, 4002
}

\begin{abstract}
COVID-19 is an unprecedented event that brings adverse effects to different countries, including the Philippines. This disease greatly affected education in the Philippines from March 2020 up to present. School heads' resiliency is one possible solution so that learning would continue. The Department of Education issued DepEd Order (DO) No. 012, s. 2020, stipulating that DepEd shall employ multiple learning delivery modalities (LDMs) to ensure the continued provision of learning opportunities to its learners, while protecting the health and safety of both its personnel and learners. This study looked into how school leaders in the DepEd Division of Laguna maintained themselves resilient. Additional highlight of this study is the investigation of how the school heads are implementing their enhanced school learning continuity plan this school year 2021-2022. With 73 school leaders participating in this study, it was found out that they have a very high resiliency level in four aspects - community cohesiveness, sustained communication, prioritizing mental and psychosocial health, and welcoming feedback. Also, the following themes were constructed: (1) All are called for unity, (2) Communication is what makes a group or team strong, (3) Health is wealth; prioritize it. (4) Listen to what feedback and survey say; they matter, (5) Proper delivery and monitoring takes learning at its best, (6) Quality technical assistance can breed quality learning, (7) Activities become meaningful when resources are shared, (8) Pandemic calls for alternative arrangement to safeguard health, (9) Support is essential, (10) Make them feel at home, not just special, and (11) Acquisition of fund is as important as proper utilization. Recommendations were given focusing on projects that can be initiated to sustain resiliency.
\end{abstract}

Keywords: pandemic; distance; leader; learning; resiliency; school

\section{Introduction and Rationale}

The striking question being heard most of the time whenever a school head gets a chance to share own work and personal life stories. Knowing the great responsibilities being put into their shoulders, plus the hustle and bustle of the profession - it is no doubt that this kind of question is something that can be commonly asked to any of them.

In the context of having too much to do and much to prepare to, undeniably, school heads and administrators are the first ones to spring to mind. Having to go through a lot of physical and even mental work demands, exhaustion is already anticipated. Moreover, the pressure to strive for competence and aim for professional growth and development is something that are always expected from them.

The idea to juggle everything in between makes the leading and managing experience to be just way too burdensome. As if everything must be done accordingly, that one wrong move will mess up all the things they have worked for - losing the morale and the high spirit they have for the demanding profession.

As a further matter, this concern is not only popular to specific group of leaders alone. Other academic administrators including supervisors and subject specialists also walk their way through the same 
narrow and difficult part of performing their tasks along various factors which hinders effective management and efficient work assignment implementation.

Not to mention the impact of the global pandemic in the education sector and its implication to the mental well-being of school heads and teachers. Amid the entire struggle, what keeps the flame burning is the resiliency of all the school heads who willingly devotes their life into the profession - even if it is less good than what they had before. But how do they really do it?

Looking back at the years of extreme hard work and sacrifice, one thing that helped them to keep going is their attitude. Perspective on various work-life conundrums and standing neutral on conflicts earned them a notable reputation. This badge of honor puts pride to their being not only as a school leader, but more so in their individual achievements.

But all these would not be possible without the help of one another, as for any leader, their strength comes from the people surrounding them - that includes teachers, stakeholders, learners, and their vision. For without all of these, none of their efforts would matter.

The primary requirement to handle everything that comes with leadership is resilience. Problems come and go - and these difficulties must be handled with optimism and hope. Through this study, an indepth presentation of school heads resiliency will be shown.

Amidst the public health emergency brought about by the COVID-19 pandemic, the Department of Education (DepEd) is committed to ensure unhampered delivery of basic education services to its learners and the community, in line with the constitutional mandate of the State "to establish, maintain and support a complete, adequate, and integrated system of education relevant to the needs of the people, the country and society-at-large," pursuant to Section 2 (1), Article XIV of the 1987 Constitution, as reiterated in Republic Act (RA) No. 10533, or the Enhanced Basic Education Act of 2013.

COVID-19 is an unprecedented event that brings adverse effects to different countries, including the Philippines. This disease greatly affected education in the Philippines from March 2020 up to the present. Hundreds of school closures are implemented because of the danger that this disease could bring. Due to its massive impact on education, educational institutions in the country take educational countermeasures to continue educating the students despite the COVID-19 difficulties. They strengthen the educational planning and health measures in every school to provide students and teachers with an opportunity to continue learning while preventing the spread of the virus. The educational system in many schools was switched from face-toface to distance learning. Some teachers made modules for modular instructions while some recorded and uploaded their lessons for the students to access online. The truth is, private and public schools are not prepared to implement this kind of system, but because education is vital for the development of the children as well as the country, many schools opted for distance education.

This is the reason why the why the Department of Education issued DepEd Order (DO) No. 012, s. 2020, "Adoption of the Basic Education Learning Continuity Plan (BE-LCP) for School Year 2020-2021 in the light of the COVID-19 Public Health Emergency," DepEd shall employ multiple learning delivery modalities (LDMs) to ensure the continued provision of learning opportunities to its learners, while protecting the health and safety of both its personnel and learners. This can be done through blended learning, distance learning, and homeschooling. This is the possible solution so that learning would continue and to apply the school heads' resiliency.

The respondents of this study are the public elementary school principals in the elementary and secondary in 25 Districts, Division of Laguna. School Year 2021-2022.

\section{Literature Review}

This section cites related readings to the present study. They will give light to the different issues or variables concerned to the focus of this study.

For school leaders working in these demanding and chaotic circumstances, the pressure is relentless, the 
options are limited, and the sleepless nights are frequent. The staff meetings, coffee catch ups and corridor chats with colleagues that made up a school day have gone. All those informal, important, moments where social relationships are built, and leadership is enacted simply vanished overnight. Parents, students, and teachers now exist in a twilight education world either awaiting the return of normal service or hoping for some new normal that might offer stability, continuity, and reassurance. The stark reality is that neither is likely to occur anytimesoon.

Meanwhile, school leaders are caught in the unfavorable position of being the pinch point in the system. They are reliant on guidance about COVID-19 responses, processes, procedures, and protocols from above. These can change, almost overnight, depending on how the virus develops. Simultaneously, school leaders are dealing with fluid and changing staffing situations meaning they are performing to do much more with less. The social distancing of staff and students means extra work and extra pressure on those staff who can return to work. Every expectation either from aboveor below asks more of school leaders professionally and personally.

There are perfect storms with imperfect leadership responses. As Netolicky (2020) noted in time of crisis, leaders must act swiftly and with foresight but also with careful tightrope without a safety net. There are no precedents and no guides to leading schools in a pandemic. There has been some early research, of course into the effects and impact of COVID 19on all sectors of education. This work has helped to set down useful markers and some preliminary reference points. Aiming to capture the dimensions of such a colossal moving target, however, will require far more sophisticated research methodologies in the future, if the work is to move to more valid and generalizablefindings (Fetters and Molina-Azorin 2020).

Despite a current lack of research on how school leaders are responding to the pandemic, there are some emerging insights about leadership within the COVID19 educational landscape. The following seven propositions are offered for considerationand possibly, in due course, empirical attention.

School leadership practices have changed considerably and maybe, irreversibly because of COVID19. As a result of the pandemic, school leadership has shifted on its axis and is unlikely return to 'normal' anytime soon, if ever at all. Research underlines that the principles of good leadership are a constant i.e. having a clear vision, developing others, managing people, building capacity etc. (Leithwood, Harris, and Hopkins 2020). The evidence also points towards the importance of context responsive leadership implying a shift in school leadership practices because of COVID19 (Harris 2020).

Most school leadership preparation and training programs prior to COVID19are likely to be out of step with the challenges facing school leaders today. In many cases, the existing preparation and training programs, along with the models of leadership they espouse, will require a radical re-think and significant modification to remain relevant for aspiring and practicing school leaders. It would be a mistake to simply re-configure or rebadge what was relevant before ongoing, COVID19 situation.

Self-care and consideration must be the main priority and prime concern for all school leaders. Leading a school through the changes and challenges that accompany COVID19 and post COVID19 will require school leaders who put their own health and wellbeing first, so that they will be able to help others. Increasingly, school leaders are managing the emotional responses of others to this crisis including anxiety, frustration loss, and anger. Consequently, self-care must be a priority for those leading schools at all levels.

The phrase 'connect to learn, learn to connect' (Harris and Jones 2012) describes the daily reality of students and teachers trying to work together in this pandemic. Hence, moving forward, school leaders will increasingly need to be technologically savvy and well informed. COVID19 has generated huge commercial opportunism with a pressure to buy technological solutions to contemporary problems. School leaders will need to be discerning therefore, about the digital products they choose and to be careful about striking a balance between technology and pedagogy in their school (Hargreaves 2020). Ultimately, pedagogy is the key toeffective learning and while technology has a part to play, it is the human dimension of effective teaching that makes the difference.

Crisis and change management are now essential skills of a school leader. Running an effective school in disruptive times will require more than routine problem solving or occasional firefighting. Instead all school leaders will need to be engaged in constant crisis and change management which will require support and 
collaboration from all staff. The speed of change in this pandemic is unprecedented, hence, a high degree of trust will be needed, as the collective glue, to ensure that issues are addressed collectively as they arise. parent/community groups to support families, young people and children is now a necessity to deal with the many issues that COVID19 has generated particularly for vulnerable, marginalized, or isolated young people.

Distributed leadership has become the default leadership response in this current crisis requiring more school leaders, at all levels, to connect, share, learn and network their way through issues (Azorín, Harris, and Jones 2020). Through absolute necessity, rather than by design, effective school leadership is now connected, collaborative, creative and responsive. Most school leaders will be running on empty given the myriad of challenges that COVID19 has created forthem, so distributed leadership is a necessity to survive.

As we move forward to construct our "new normal" in the wake of the COVID-19 pandemic, we must therefore recognize that along with the economy and health care system, schools are an essential third pillar in promoting community resilience and rebuilding communities' physical, economic, emotional, social, and cultural health. Supporting schools amid the pandemic is thus about much more than re- configuring learning opportunities, as crucial as that is. In fact, focusing solely on schools' capacities to provide highquality remote learning opportunities to students at scale may perversely weaken communities by failing to recognize schools' diverse and far-reaching roles in promoting community resilience through non-teaching roles such as child care, social welfare services, and stable adult employment. Pandemic-resilient schools can (and are essential to) contribute to a pandemic-resilient society (Allen et al., 2020) when they are capable of fulfilling each of the five essential roles they have historically played in promoting pre-pandemic community resilience: social welfare services, human development, child care, employment, and democratic solidarity. Yet the long-term closures that the pandemic requires have made it difficult, if not impossible, for schools to perform any of these roles. The shift to remote education has laid bare deep educational in- equities, as many students are not able even to access online schools or much-needed resources. With brick-and-mortar schools closed, parents across the country struggle to balance child care, educational instruction, and their jobs. And schools' role as employers - in many communities the single-largest local employer capable of providing middle-class or living wages - is facing the threat of severe budget cuts that may force them to lay off or furlough substantial portions of their workforces (Litvinov, 2020; Strauss, 2020). Even when schools have been able to sustain one of these crucial roles - namely, their ability to continue food distribution to students and families — cracks have become evident. Many eligible families have been unable to pick up food because of essential work schedules or lack of transportation (DeParle, 2020), and increasing numbers of Americans who are food insecure for the first time because of the pandemic-induced shutdown are reaching out to schools for support (Bauer, 2020). It isunclear whether schools have the resources to meet this growing need.

As the pandemic continues to shake the foundations of the country's economy and social fabric, schools need support along each of the five dimensions of community resilience so that they, in turn, can sup-port the families and communities who rely on them in so many different and vital ways. In what follows, we detail each of these sources of resilience and the impact of the pandemic on schools' ability to realize them. We then offer a series of recommendations for policymakers that would enable schools to sustain communities during this moment of global crisis.

K-12 schools also provide physical and mental health services to millions of students per year, including vaccinations; management for chronic diseases such as diabetes, asthma, or ADHD; sexual and reproductive health education and services; vision, dental and mental health screenings and services; nutrition health education; and hypertension screening (Baltag et al., 2015). School nurses and counselors are particularly powerful providers of care (Maughan, 2018); recent studies have found that about three-quarters of students who receive any mental health services get them in their schools, for instance, and that students are "21 times more likely to visit school-based health centers for mental health services get them in their schools, for instance, and that students are " 21 times more likely to visit school-based health centers for mental health than community mental health centers" (Whitaker etal., [2019]). Although the nationwide shortage of nurses has made it hard for schools, like community health centers and hospitals, to maintain adequate staffing levels 
(Washburn, 2019), U.S. schools stillemploy approximately 95,800 FTE nurses to serve a population of about 55 million students (Willgerodt, 2018). Vital health services are also provided by 111,000 school counselors, 32,000 social workers, and 41,000 school psychologists (as of 2012; see NCES, 2012). Often these providers are the first point of care, especially in under-resourced areas (Whitaker et al., [2019]); about a quarter of students served by a dental outreach program in Michigan, for example, had never seen a dentist before (Albanese, 2014), and over 6,500 students in Baltimore Public Schools have received glasses since 2016 thanks to school-based screenings (Hub Staff, 2019). Unfortunately, availability does not fully match need. The most vulnerable students often attend schools in districts with the worst ratio of counselors and nurses to students (Willgerodt et al., 2018; Gagnon \& Mattingly, 2016; CLASP, 2015). This is one of the reasons teachers went on strike in Los Angeles Unified and Oakland, California, in 2018 and 2019; the unions made increased nursing capacity a key demand (Washburn, 2019) and won concessions inboth cases.

Modern societies rely on two central institutions to work in tandem to support children's educational development - the school system and the family. This partnership supports community resilience in twodifferent ways. First, schools are vital partners in the shared work of child development. While children's home environments have significant impact on their school-based learning (Coleman, 1966; Osher et al., 2020; Reardon, 2011), schools are primary sites of formal academic, social-emotional, civic, and vocational learning for the vast majority of children in the U.S. As many parents have been dismayed to discover while trying to homeschool during the pandemic, teaching algebra, reading, coding, or music requires specialized knowledge and skills, which professional teachers have and parents generally lack. By bringing numerous children and adults together into one shared space, schools also provide young people opportunities to develop friendships and other meaningful relationships, to develop emotional regulation and executive function skills beyond the family setting, to develop civic knowledge and habits of civic engagement, and to gain valuable workplace skills including group work skills and vocation- specific skills such as nursing or car repair. Schools can also harness economies of scale unavailable to families because a single teacher can educate multiple children at a similar stage of development at a time. Furthermore, schools can improve the prospects of students whom our society systematically disadvantages in other ways. U.S. schools are characterized by deep disparities in achievement and opportunity, by race and class in particular, but there is also good reason to believe that without schools, these disparities would be even larger (Reardon, 2011; Center on Education Policy, 2007).

Second, schools support long-term community resilience by providing individuals with the knowledge and skills necessary for sustaining collective community life. In addition to the effects of education for individuals, we all collectively benefit from higher levels of educational goods in the population. High levels of education enable greater economic productivity, quicker and better solutions to social and economic problems, and greater and more complex cultural production, not to mention healthier and longer lives (Sen, 2009; Mcgregor, 1994; Moretti, 2004a, 2004b). Never is this clearer than in a major public health crisis in which we rely not just on the dedication and commitment of health professionals, but also on their knowledge and skills.

Yet, the pandemic has disrupted the traditional division of labor between families and schools, affecting both the short- and long-term ways that human development supports community resilience. Schools typically promote human development through embodied, synchronous interaction: teachers and students are in the same room at the same time, and whatever work they do outside that room, alone or with others, is organized around that embodied interaction. That is exactly what schools cannot do during a pandemic: public health precautions require teachers and students to be physically isolated fromone another.

Schools have thus shifted to using alternative modes of delivery. In fact, in just eleven days during the pandemic, the percentage of schools providing remote learning increased from 43 to $71 \%$ (Malkus \& Christensen, 2020b), and by late April virtually all schools and districts had remote learning plans in place (Malkus \& Christensen, 2020c). Despite classroom closures, teachers in $60 \%$ of schools have been encouraged to connect with their students through synchronized video lessons, independent- learning platforms, or email (Malkus \& Christensen, 2020a). But without training, practice, preparation, or a proven infrastructure, these efforts have 
proven to be substantially less effective at driving learning than traditional in-person modes of instruction (Goldstein, 2020; Reich et al, 2020). Furthermore, the evidence suggests that the "online penalty" (Dynarski, 2018) has proven even harsher for already vulnerable students, in particular low-income students, students with disabilities, and students in historically marginalized schools and communities (Goldstein, 2020).

Most parents are ill-equipped to step fully into teachers' educational roles even under propitious circumstances. Teaching is already a complex task that requires professional judgment and expertise that most parents lack (Alterator et al., 2018; Parker \& Hess, 2001; Shulman, 1986). On top of that, most parents are either trying to balance an increased role in educating their children with the other job theywere already doing, or are trying to educate their children while they endure the stresses associated with the loss of the job they were previously doing (Long, 2020; Harris, 2020). The vast majority of parents cannot simply step into the role of teacher and do so effectively.

Public health concerns justify the closure of schools in most places right now, despite the costs to individual and collective human development. But there is every reason to suspect that those costs will be substantial (Dorn et al., 2020). This will be especially true for students whose families are particularly stressed by the virus, whether because they are in populations that are disadvantaged due to U.S. socioeconomic and racial structures, or because their parents work in positions that are vulnerable to infection, or because they are sick, or because they have special educational needs (Kelly \& King, 2020; Kufeld \& Tarasawa, 2020). Parents struggle as a result of school closure in different ways given the varying impact of the pandemic on their ability to work. Far too many parents have lost their jobs as a result of the pandemic. In addition to providing care for their children, they may be searching for work, navigating overwhelmed unemployment offices, or fighting with landlords about rent (McCarthy et al., 2020). Most parents of school-age children who have not lost jobs continue to work. Yet now they must do so while they balance childrearing fulltime - a challenge that has led to reported declines in family well-being within a week following a stay-at-home requirement (Ananat \& Gassman-Pines, 2020). Through social media and widely shared opinion columns, parents offer glimpses into their reality. Two-parent families struggle to adapt to various coping strategies, including alternating work hours or working early or late in the day if their job allows (Manjoo, 2020), while single-parent families face even steeper obstacles (Bobrow, 2020). Some schools have attempted to ameliorate parents' child care obligations through providing synchronous classes or assigning projects and other school work designed to occupy students for long stretches of time. While this has proved a boon for some families, it has imposed additional burdens on others whose children need extra support to access the technology or complete the work. Particularly for families with young children, children with special needs, or multiple siblings, managing school work adds to thechild care burden rather than relieving it (Cavanagh \& Fox, 2020; Parcak, 2020).

Schools serve as sites and sources of community resilience in five distinct ways: they distribute social welfare services, promote human development, care for children, provide stable employment, and strengthen democratic solidarity. Yet long-term physical school closures-along with impending budget cuts driven by cratering state and local economies and tax revenues - make it extremely difficult for schools to perform any of these roles. We recommend three steps for restoring schools' capacities to support community resilience. First, state and district leaders should set metrics for achieving access and equity in each of the five roles that schools play, not just in academic achievement. Second, to establish these metrics, policymakers should develop or strengthen mechanisms to engage diverse community voices, as local community members often best understand the specific ways in which their own schools support or impede community resilience. Finally, Congress should allocate significant increases in federal funding to support public schools and districts for at least the next two years; these allocations should include strong supports for high- needs districts in particular.

\section{Research Questions}

This study will focus on exploring the different ways in which school leaders in Victoria, Laguna were able to continue delivering quality education amidst pandemic. 
Specifically, it will seek to answer the following questions:

1. What is the mean level of resiliency of the school leaders in terms of the following:

a. Promotion of community cohesiveness;

b. Sustained communication;

c. Attention to mental and psychosocial health;

d. Welcoming feedback;?

2. How can schools promote a cohesive community among teachers, learners and stakeholders?;

3. What can schools do to have a sustained communication and continuous delivery of important information?;

4. How should mental and psychosocial health be prioritized in this time of pandemic?; and

5. In what ways can feedback be gathered and dealt with so as to provide action or solution?

6. What are the key actions that the schools are undertaking under the following enhanced school learning continuity plan dimensions:
a. Focus on learning;
b. Ensuring quality of teaching and learning process;
c. Provision of learning resources;
d. Safe operations;
e. Well-being and protection;
f. Reaching the marginalized; and
g. Education funding

\section{Scope and Limitation}

This study was able to reach 73 public elementary and secondary school heads in DepEd Schools Division Office of Laguna as the respondents in questionnaire. The concepts or conclusions formed may be seen as applicable only during this time of pandemic but the general ideas can cover times of normal situation, as collaboration to parents and community, constant communication, welcoming feedback and attention to psychosocial and mental health are all important aspects for a growing and developing institution.

\section{Research Methodology}

\subsection{Sampling}

The respondents of this study are the public elementary and secondary school heads in 25 districts in Division of Laguna. This study was conducted during the school year 2021-2022.

\subsection{Data Collection}

The researchers sought to determine the School Heads' Resiliency in the Division of Laguna through informed consent to conduct the online survey. After the permission was secured, survey, online survey questions was uploaded in a google form and encoded them. Then data from the answered survey questionnaires was tallied and treated statistically for the interpretation.

To answer statements of the problem, the following instruments were used:

For statement of the problem number 1 , an online survey questions were used to find the mean level of resiliency of the school leaders in terms of promotion of community cohesiveness, Sustained communication, attention to mental and psychosocial health, and welcoming feedback using the Likert evaluation system.

$$
\text { 4.21-5.00 Very High Level of Resiliency }
$$


3.41-4.20 High Level of Resiliency

2.61-3.40 Moderate Level of Resiliency

1.81-2.60 Low Level of Resiliency

1.00-1.80 Very Low Level of Resiliency

For statement of the problem number 2-6, an open-ended interview was done using also the google form platform.

\section{Discussion of Results and Recommendations}

\subsection{Promotion of Community Cohesiveness}

Table 1. School leaders' level of resiliency in terms of promotion of community cohesiveness

\begin{tabular}{|c|c|c|c|}
\hline Indicators & Mean & SD & Interpretation \\
\hline 1. Teachers support each other in delivering quality education. & 4.75 & 0.43 & Very High Level of Resiliency \\
\hline 2. Learners respond to the schools' requirement promptly. & 4.22 & 0.61 & Very High Level of Resiliency \\
\hline $\begin{array}{l}\text { 3. Stakeholders' commitment is seen through concerted effort to } \\
\text { help the school. }\end{array}$ & 4.41 & 0.57 & Very High Level of Resiliency \\
\hline $\begin{array}{ll} & \text { Average }\end{array}$ & 4.46 & 0.54 & Very High Level of Resiliency \\
\hline
\end{tabular}

Legend: $\quad 4.21-5.00$ Very High Level of Resiliency

$3.41-4.20$ High Level of Resiliency

$2.61-3.40$ Moderate Level of Resiliency

$1.81-2.60$ Low Level of Resiliency

$1.00-1.80$ Very Low Level of Resiliency

The table above shows the level of resiliency of school leaders in the Division of Laguna in terms of promotion of community cohesiveness. There are 73 school leaders who were able to access the Google Form containing a survey pertaining to school leaders' resiliency and implementation of the enhanced school learning continuity plan. Teachers supporting each other in quality education delivery gained a mean value of 4.75, standard deviation (SD) of 0.43 , and an equivalent interpretation of very high level of resiliency. Learners responding to the schools requirement promptly obtained a mean value of 4.22 , SD of 0.61 , and an interpretation of very high level of resiliency. Stakeholders' commitment being seen through their concerted effort gained a mean value of 4.41, SD of 0.57 , and an interpretation of very high level of resiliency. Overall, the 73 school leaders' resiliency in terms of promotion of community cohesiveness has a mean value of 4.46, SD of 0.54 , and an interpretation of very high level of resiliency. The standard deviations which are all less than 1 signify harmony in the responses of the school leaders.

\subsection{Sustained Communication}

Table 2. School leaders' level of resiliency in terms of promotion of sustained communication

\begin{tabular}{|c|c|c|c|}
\hline Indicators & Mean & SD & Interpretation \\
\hline $\begin{array}{l}\text { 1. Virtual meetings or other means of communication in social } \\
\text { media are prevalent and being implemented for teachers, parents } \\
\text { and learners. }\end{array}$ & 4.58 & 0.58 & Very High Level of Resiliency \\
\hline $\begin{array}{l}\text { 2. News and updates are being posted on common platform of } \\
\text { communication. }\end{array}$ & 4.63 & 0.51 & Very High Level of Resiliency \\
\hline 3. Webinars for parents and teachers are regularly scheduled. & 4.18 & 0.73 & High Level of Resiliency \\
\hline $\begin{array}{ll} & \text { Average }\end{array}$ & 4.46 & 0.61 & Very High Level of Resiliency \\
\hline $\begin{array}{ll}\text { Legend: } & 4.21-5.00 \text { Very High Level of Resiliency } \\
& 3.41-4.20 \text { High Level of Resiliency } \\
& 2.61-3.40 \text { Moderate Level of Resiliency } \\
& 1.81-2.60 \text { Low Level of Resiliency } \\
& 1.00-1.80 \text { Very Low Level of Resiliency }\end{array}$ & & & \\
\hline
\end{tabular}


The table above shows the level of resiliency of school leaders in the Division of Laguna in terms of sustained communication. Prevailing virtual meeting or other means of communication in social media gained a mean value of 4.58, standard deviation (SD) of 0.58 , and an equivalent interpretation of very high level of resiliency. Posting of news and updates on common platform obtained a mean value of 4.63, SD of 0.51 , and an interpretation of very high level of resiliency. Regular scheduling of webinars for parents and teachers gained a mean value of 4.18 , SD of 0.73 , and an interpretation of very high level of resiliency. Overall, the 73 school leaders' resiliency in terms of sustained communication has a mean value of 4.46, SD of 0.61 , and an interpretation of very high level of resiliency. The standard deviations which are all less than 1 signify harmony in the responses of the school leaders.

\subsection{Attention to Mental and Psychosocial Health}

Table 3. School leaders' level of resiliency in terms of promotion of attention to mental and psychosocial health

\begin{tabular}{|c|c|c|c|}
\hline Indicators & Mean & SD & Interpretation \\
\hline $\begin{array}{l}\text { 1. Brochures, pliers or information in social media about } \\
\text { maintaining good standing of mental and psychosocial health are } \\
\text { disseminated to parents, teachers, learners and stakeholders. }\end{array}$ & 4.33 & 0.58 & Very High Level of Resiliency \\
\hline $\begin{array}{l}\text { 2. Webinars or virtual seminars are provided to the school and } \\
\text { community. }\end{array}$ & 4.38 & 0.64 & Very High Level of Resiliency \\
\hline $\begin{array}{l}\text { 3. Mental and psychosocial concern and support are implied } \\
\text { through school policies being promulgated from the school } \\
\text { administration. }\end{array}$ & 4.62 & 0.52 & Very High Level of Resiliency \\
\hline $\begin{array}{ll} & \text { Average }\end{array}$ & 4.44 & $\mathbf{0 . 5 8}$ & Very High Level of Resiliency \\
\hline
\end{tabular}

Legend: $4.21-5.00$ Very High Level of Resiliency

$3.41-4.20$ High Level of Resiliency

$2.61-3.40$ Moderate Level of Resiliency

$1.81-2.60$ Low Level of Resiliency

$1.00-1.80$ Very Low Level of Resiliency

The table above shows the level of resiliency of school leaders in the Division of Laguna in terms of attention of mental and psychosocial health. Dissemination of brochures, pliers or information in social media about maintaining good standing of mental and psychosocial health gained a mean value of 4.33, standard deviation (SD) of 0.58 , and an equivalent interpretation of very high level of resiliency. Provision of webinars or virtual seminars to the school and community obtained a mean value of 4.38 , SD of 0.64 , and an interpretation of very high level of resiliency. Implication of mental and psychosocial concern and support gained a mean value of 4.62, SD of 0.52 , and an interpretation of very high level of resiliency. Overall, the 73 school leaders' resiliency in terms of attention to mental and psychosocial health has a mean value of 4.44 , $\mathrm{SD}$ of 0.58 , and an interpretation of very high level of resiliency. The standard deviations which are all less than 1 signify harmony in the responses of the school leaders.

\subsection{Welcoming Feedback}

Table 4. School leaders' level of resiliency in terms of promotion of welcoming feedback

\begin{tabular}{|c|c|c|c|}
\hline Indicators & Mean & SD & Interpretation \\
\hline $\begin{array}{l}\text { 1. The school has provided teachers, learners and the community a } \\
\text { way to lay down their feedback on school system. }\end{array}$ & 4.52 & 0.56 & Very High Level of Resiliency \\
\hline $\begin{array}{l}\text { 2. Feedbacks in social media or other means are being given } \\
\text { attention or solution. }\end{array}$ & 4.52 & 0.60 & Very High Level of Resiliency \\
\hline $\begin{array}{l}\text { 3. Feedbacks are seen to be essential for school growth and } \\
\text { progress. }\end{array}$ & 4.63 & 0.51 & Very High Level of Resiliency \\
\hline $\begin{array}{lc}\text { Average } & \text { Ave }\end{array}$ & 4.56 & 0.56 & Very High Level of Resiliency \\
\hline
\end{tabular}


Legend: $4.21-5.00$ Very High Level of Resiliency

$3.41-4.20$ High Level of Resiliency

2.61 - 3.40 Moderate Level of Resiliency

$1.81-2.60$ Low Level of Resiliency

$1.00-1.80$ Very Low Level of Resiliency

The table above shows the level of resiliency of school leaders in the Division of Laguna in terms of welcoming feedback. Provision of ways to teachers, learners and the community in laying down feedback gained a mean value of 4.52, standard deviation (SD) of 0.56 , and an equivalent interpretation of very high level of resiliency. Giving attention to feedbacks in social media or other means obtained a mean value of 4.52 , SD of 0.60 , and an interpretation of very high level of resiliency. Considering feedbacks as essential for school growth and progress gained a mean value of 4.56, SD of 0.56 , and an interpretation of very high level of resiliency. Overall, the 73 school leaders' resiliency in terms of welcoming feedback has a mean value of 4.56 , SD of 0.56 , and an interpretation of very high level of resiliency. The standard deviations which are all less than 1 signify harmony in the responses of the school leaders.

\subsection{Promoting Cohesiveness among Teachers, Learners and Stakeholders}

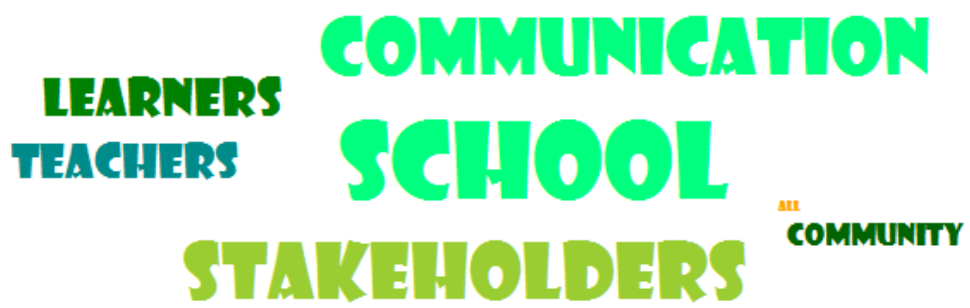

Fig. 1. 2D-word cloud of frequently appearing words in promoting cohesiveness

Table 5. Frequently appearing words in promoting cohesiveness

\begin{tabular}{|l|l|l|}
\hline No. & Word & Frequency \\
\hline 1 & school & 40 \\
\hline 2 & communication & 32 \\
\hline 3 & stakeholders & 32 \\
\hline 4 & learners & 25 \\
\hline 5 & teachers & 24 \\
\hline 6 & community & 19 \\
\hline 7 & all & 15 \\
\hline
\end{tabular}

The 2D Word Cloud and the table present the frequently appearing words in the response of the 73 school leaders in the Division of Laguna to the qualitative question "How can schools promote a cohesive community among teachers, learners and stakeholders?" The first six frequently appearing words are already given, that is, most likely to be seen frequently in the responses because they are the composition of the topic of the qualitative question. The interesting word is "all". The theme developed for this aspect of resiliency is:

Theme 1: "All are called for unity."

In promoting cohesiveness among teachers, learners and stakeholders, each one should consider themselves as part of the team that needs unity in direction, unity in goal, and unity in aspiration. If one among these subgroups (teachers, learners, or stakeholders) would not give their utmost contribution, the 
resiliency of the system falls down, and it will also affect the resiliency of the school head. The teachers, learners and stakeholders should not just think of the collaboration as a group effort, but more importantly, team effort. This means having care and concern for each other's welfare, lifting up others when they are down, and encouraging those are lagging behind.

6.6. Sustaining Communication and Continuous Delivery of Quality Service

\section{IMPORTANT \\ DAE CROUP MFORMATHON \\ SCHOOL -.. COMMUNICATION}

Fig. 2. 2D-word cloud of frequently appearing words in sustaining communication

Table 6. Frequently appearing words in sustaining communication

\begin{tabular}{|l|l|l|}
\hline No. & Word & Frequency \\
\hline 1 & school & 38 \\
\hline 2 & communication & 36 \\
\hline 3 & information & 20 \\
\hline 4 & group & 16 \\
\hline 5 & important & 16 \\
\hline 6 & learners & 14 \\
\hline 7 & page & 14 \\
\hline
\end{tabular}

The 2D Word Cloud and the table present the frequently appearing words in the response of the 73 school leaders in the Division of Laguna to the qualitative question "What can schools do to have a sustained communication and continuous delivery of important information?" The six frequently appearing words are already given, that is, most likely to be seen frequently in the responses because they are the composition of the topic of the qualitative question. The interesting word is "group". The theme developed for this aspect of resiliency is:

Theme 2: Communication is what makes a group or team strong.

In sustaining communication and continuous delivery for of quality service, each part or member of the group should have clear and specified job description, in such a way that they know what is expected of them. More so, the members of the group, upon proper communication, should also know what will happen if they will not perform their specific task in a week, month, or regular interval. The comprehensive concept of a group effort that has a proper communication will sure meet their goal and attain success.

\subsection{Considering Mental and Psychosocial Health}

The 2D Word Cloud and the table present the frequently appearing words in the response of the 73 school leaders in the Division of Laguna to the qualitative question "How should mental and psychosocial health be given attention in this time of pandemic?" The first six frequently appearing words are already given, that is, most likely to be seen frequently in the responses because they are the composition of the topic 
of the qualitative question. The interesting word is "prioritized". The theme developed for this aspect of resiliency is:

\section{Theme 3: Health is wealth; prioritize it.}

In considering mental and psychosocial health as vital aspect of learning delivery, the school is becoming holistic in looking at the aspects greatly affected by pandemic, not just physical health. When mental and psychosocial health is prioritized, other aspects like motivation in learning, enthusiasm at work, and health relationship of the school and community, are all being attained. Webinars and info-graphics with regards to mental and psychosocial health indeed really helps so that the elements of educational system can proceed in delivering quality education.

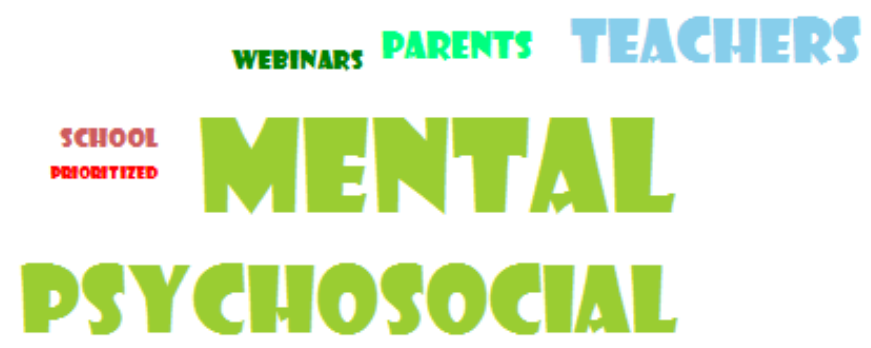

Figure 3. 2D-word cloud of frequently appearing words in mental and psychosocial health

Table 7. Frequently appearing words in mental and psychosocial health

\begin{tabular}{|l|l|l|}
\hline No. & Word & Frequency \\
\hline 1 & mental & 42 \\
\hline 2 & psychosocial & 32 \\
\hline 3 & teachers & 23 \\
\hline 4 & parents & 17 \\
\hline 5 & webinars & 14 \\
\hline 6 & school & 14 \\
\hline 7 & prioritized & 12 \\
\hline
\end{tabular}

6.8. Attending to Feedback for Action and Solution

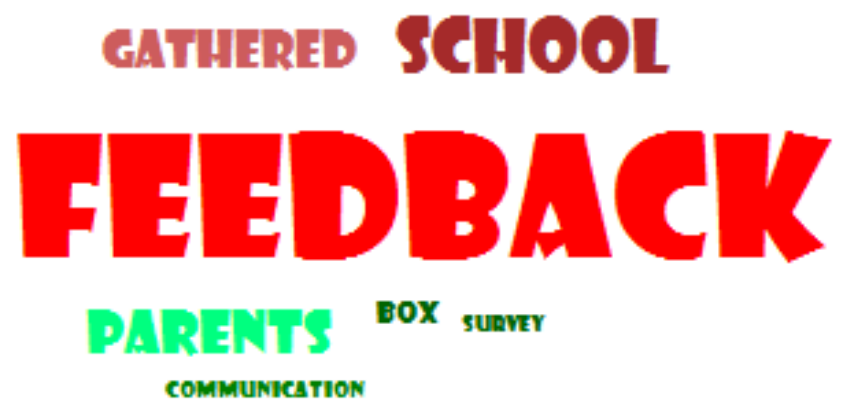

Fig. 4. 2D-word cloud of frequently appearing words in welcoming feedback 
Table 8. Frequently appearing words in welcoming feedback

\begin{tabular}{|l|l|l|}
\hline No. & Word & Frequency \\
\hline 1 & feedback & 33 \\
\hline 2 & School & 19 \\
\hline 3 & parents & 17 \\
\hline 4 & gathered & 16 \\
\hline 5 & box & 13 \\
\hline 6 & survey & 12 \\
\hline 7 & communication & 12 \\
\hline
\end{tabular}

The 2D Word Cloud and the table present the frequently appearing words in the response of the 73 school leaders in the Division of Laguna to the qualitative question " In what ways can feedback be gathered and dealt with so as to provide action or solution?" The other six frequently appearing words are already given, that is, most likely to be seen frequently in the responses because they are the composition of the topic of the qualitative question. The interesting word is "survey". The theme developed for this aspect of resiliency is:

Theme 4: Listen to what feedback and survey say; they matter.

Someone said, "The sure thing that the survey says is that surveys do not lie." Neglecting at the feedback and responses from surveys would mean stagnation to the system because they would just go without the hints and warnings that the people in the education system are noticing. Feedbacks, however negative they are, should be given attention and be considered as great advice for the education development and growth. When those feedbacks are given attention, openness of the system is seen, and the healthier the institution would be.

The four themes constructed for school head's resiliency are as follows:

1. All are called for unity.

2. Communication is what makes a group or team strong.

3. Health is wealth; prioritize it.

4. Listen to what feedback and survey say; they matter.

\subsection{E-SLCP (Enhanced School Learning Continuity Plan) Implementation: Focus on Learning}

The 2D Word Cloud and the table present the frequently appearing words in the response of the 73 school leaders in the Division of Laguna to the qualitative question "In the aspect of BE-SLCP Implementation, provide key action that your school will undertake under the dimension "focus on learning"?" The other five frequently appearing words are already given, that is, most likely to be seen frequently in the responses because they are the composition of the topic of the qualitative question. The interesting word is "monitoring" and "delivery". The theme developed for this aspect of resiliency is:

Theme 5: Proper delivery and monitoring takes learning at its best.

Proper delivery of knowledge and coordinated process of teaching matters most in this time of pandemic, whether it is modular distance learning, online distance learning, or blended. But just providing activity learners, no matter how carefully constructed and thought of, would be wasted if there is no monitoring. There should be a well-established monitoring so as to secure the continuity of learning and progress of every child. Constant communication to learners and stakeholders through social media and other means of communication is an additional task of teachers and school heads, but would secure academic progress when sincerely done. 


\section{PARENTS \\ MONITORING WhL SCHOOL \\ LEARNERS LEARNING}

Fig. 5. 2D-word cloud of frequently appearing words in focus on learning

Table 9. Frequently appearing words in welcoming feedback focus on learning

\begin{tabular}{|l|l|l|}
\hline No. & Word & Frequency \\
\hline 1 & learners & 33 \\
\hline 2 & learning & 32 \\
\hline 3 & school & 14 \\
\hline 4 & will & 11 \\
\hline 5 & monitoring & 10 \\
\hline 6 & parents & 9 \\
\hline 7 & delivery & 8 \\
\hline
\end{tabular}

6.10. E-SLCP Implementation: Ensuring Quality of Teaching and Learning
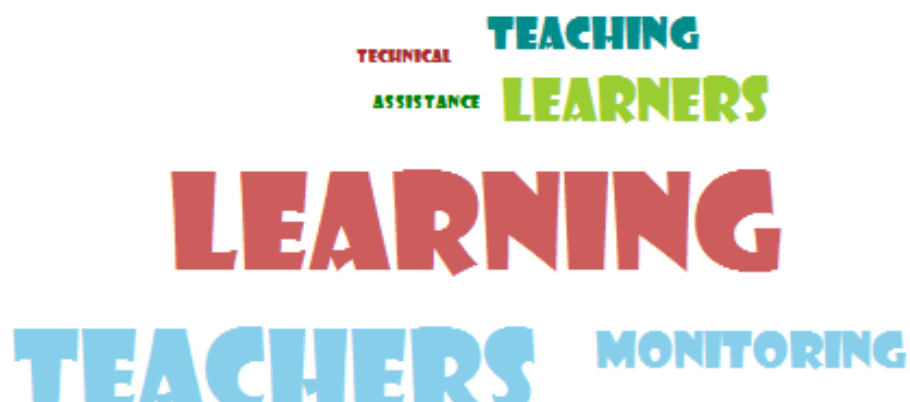

Fig. 6. 2D-word cloud of frequently appearing words in ensuring quality of teaching and learning

Table 10. Frequently appearing words in ensuring quality of teaching and learning

\begin{tabular}{|l|l|l|}
\hline No. & Word & Frequency \\
\hline 1 & learning & 27 \\
\hline 2 & Teachers & 23 \\
\hline 3 & learners & 15 \\
\hline 4 & Monitoring & 14 \\
\hline 5 & teaching & 13 \\
\hline 6 & technical & 9 \\
\hline 7 & assistance & 9 \\
\hline
\end{tabular}

The 2D Word Cloud and the table presents the frequently appearing words in the response of the 73 
school leaders in the Division of Laguna to the qualitative question "In the aspect of BE-SLCP Implementation, provide key action that your school will undertake under the dimension "ensuring quality of teaching and learning?" The first five frequently appearing words are already given, that is, most likely to be seen frequently in the responses because they are the composition of the topic of the qualitative question. The interesting word is "technical" and "assistance". The theme developed for this aspect of resiliency is:

Theme 6: Quality technical assistance can breed quality learning.

The Department of Education is saluted for initiating projects that provides technical assistance to all teachers. The sudden shift from face-to-face to distance learning which started last March of 2020 provided difficulty in assuring quality of teaching and learning. But DepEd did not stop thinking of up-skilling teachers so they can adopt to the pandemic situation and provide the needs of learners. Technical assistance should not be only given to teachers, but to learners as well. Projects of the government like provision of free education online account to learners greatly help in ensuring quality teaching and learning.

\subsection{E-SLCP Implementation: Provision of Learning Resources}

\section{LEARNING MATERIALS RESOURCES}

Fig. 7. 2D-word cloud of frequently appearing words in provision of learning resources

Table 11. Frequently appearing words in provision of learning resources

\begin{tabular}{|l|l|l|}
\hline No. & Word & Frequency \\
\hline 1 & learning & 40 \\
\hline 2 & materials & 22 \\
\hline 3 & modules & 17 \\
\hline 4 & resources & 15 \\
\hline 5 & SLMs & 13 \\
\hline 6 & Provide & 11 \\
\hline 7 & activity & 11 \\
\hline
\end{tabular}

The 2D Word Cloud and the table present the frequently appearing words in the response of the 73 school leaders in the Division of Laguna to the qualitative question "In the aspect of BE-SLCP Implementation, provide key action that your school will undertake under the dimension "provision of learning resources"?" The first six frequently appearing words are already given, that is, most likely to be seen frequently in the responses because they are the composition of the topic of the qualitative question. The interesting word is "activity". The theme developed for this aspect of resiliency is:

Theme 7: Activities become meaningful when resources are shared. 
Activities that can be found in learning portals are now being accessed at a large scale. Educators uploading their resources in learning portals are highly appreciated because when resources are shared, activities and learning become meaningful. "Two heads are better than one." When educators combine their knowledge and expertise in producing learning resources, the best outputs in education is achieved.

\subsection{E-SLCP Implementation: Safe Operations}

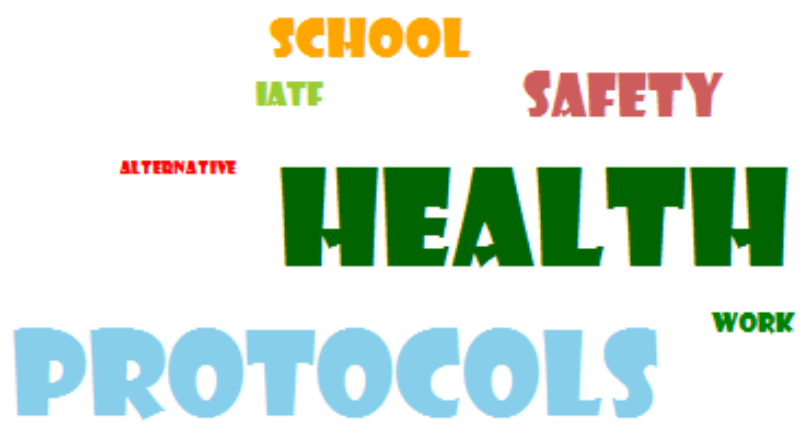

Figure 8. 2D-word cloud of frequently appearing words in safe operations

Table 12. Frequently appearing words in safe operations

\begin{tabular}{|l|l|l|}
\hline No. & Word & Frequency \\
\hline 1 & health & 45 \\
\hline 2 & protocols & 40 \\
\hline 3 & safety & 25 \\
\hline 4 & school & 24 \\
\hline 5 & IATF & 19 \\
\hline 6 & work & 17 \\
\hline 7 & alternative & 15 \\
\hline
\end{tabular}

The 2D Word Cloud and the table present the frequently appearing words in the response of the 73 school leaders in the Division of Laguna to the qualitative question "In the aspect of BE-SLCP Implementation, provide key action that your school will undertake under the dimension "safe operations"?" The first six frequently appearing words are already given, that is, most likely to be seen frequently in the responses because they are the composition of the topic of the qualitative question. The interesting word is "alternative". The theme developed for this aspect of resiliency is:

Theme 8: Pandemic calls for alternative arrangement to safeguard health.

Alternative work arrangement has to be created not just for whims of those who just want to stay at home and do unproductive things. The notion of safeguarding their health and ensuring continuous delivery of knowledge and competency should be the outstanding concern. If teachers can stay at home and at the same time do their task in teaching, they should not be given the task to regularly, physically report in school. Conformity and fairness should not be the issue in letting the education personnel secure themselves at home while productively working and contributing. 


\section{pSYCHOSOCIII MENTAL MEALTH}

\section{SCHOOL}

LEARNERS

Figure 9. 2D-word cloud of frequently appearing words in well-being and protection

Table 13. Frequently appearing words in well-being and protection

\begin{tabular}{|l|l|l|}
\hline No. & Word & Frequency \\
\hline 1 & health & 34 \\
\hline 2 & mental & 26 \\
\hline 3 & psychosocial & 19 \\
\hline 4 & school & 15 \\
\hline 5 & learners & 13 \\
\hline 6 & teachers & 12 \\
\hline 7 & support & 12 \\
\hline
\end{tabular}

The 2D Word Cloud and the table presents the frequently appearing words in the response of the 73 school leaders in the Division of Laguna to the qualitative question "In the aspect of BE-SLCP Implementation, provide key action that your school will undertake under the dimension "well-being and protection"?" The first six frequently appearing words are already given, that is, most likely to be seen frequently in the responses because they are the composition of the topic of the qualitative question. The interesting word is "support". The theme developed for this aspect of resiliency is:

Theme 9: Support is essential.

We all need each other more than any other time of our generation. Support can be shown through constant encouragement between teachers and learners, between superiors and subordinates, between parents and learners, and between teachers and parents. Understanding of the situation and allowance for unattended roles due to pandemic issues should be promulgated, while commitment to the institution's mission and vision still be kept and pursued.

\subsection{E-SLCP Implementation: Reaching the Marginalized}

The 2D Word Cloud and the table presents the frequently appearing words in the response of the 73 school leaders in the Division of Laguna to the qualitative question "In the aspect of BE-SLCP Implementation, provide key action that your school will undertake under the dimension "reaching the marginalized"?" The first five frequently appearing words are already given, that is, most likely to be seen frequently in the responses because they are the composition of the topic of the qualitative question. The interesting word are "home" and "special". The theme developed for this aspect of resiliency is: 
Theme 10: Make them feel at home, not just special.

Marginalized group do not only refer to indigenous people residing our community. Marginalized are those treated as insignificant or peripheral, seen as just on the side and not on the limelight. They can be discriminated or not given importance as part of the norm. Alternative-learning-system completers and returning students (those who stopped for a year or so, and returns in schooling this time of pandemic) can be considered in this group if they are not given special attention. There should be programs or projects in educational institutions for such groups to tap their skills and talents, thereby making them feel not just special, but also part of the family.

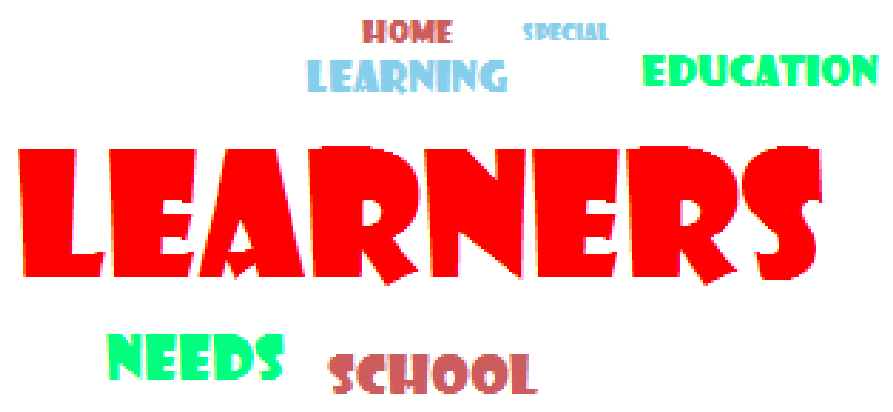

Fig. 10. 2D-word cloud of frequently appearing words in reaching the marginalized

Table 14. Frequently appearing words in reaching the marginalized

\begin{tabular}{|l|l|l|}
\hline No. & Word & Frequency \\
\hline 1 & learners & 33 \\
\hline 2 & needs & 15 \\
\hline 3 & school & 14 \\
\hline 4 & learning & 12 \\
\hline 5 & education & 12 \\
\hline 6 & home & 10 \\
\hline 7 & special & 9 \\
\hline
\end{tabular}

6.15. E-SLCP Implementation: Education Funding

\section{STAKEHOLDERS \\ PROPER \\ RESOURCES \\ SCHOOL FUNDS}

Fig. 11. 2D-word Cloud of frequently appearing words in education funding 
Table 15. Frequently appearing words in education funding

\begin{tabular}{|l|l|l|}
\hline No. & Word & Frequency \\
\hline 1 & MOOE & 30 \\
\hline 2 & school & 25 \\
\hline 3 & stakeholders & 23 \\
\hline 4 & funds & 18 \\
\hline 5 & resources & 15 \\
\hline 6 & Proper & 14 \\
\hline 7 & utilization & 13 \\
\hline
\end{tabular}

The 2D Word Cloud and the table presents the frequently appearing words in the response of the 73 school leaders in the Division of Laguna to the qualitative question "In the aspect of BE-SLCP Implementation, provide key action that your school will undertake under the dimension "education funding"?" The first six frequently appearing words are already given, that is, most likely to be seen frequently in the responses because they are the composition of the topic of the qualitative question. The interesting word is "utilization". The theme developed for this aspect of resiliency is:

Theme 11: Acquisition of fund is as important as proper utilization.

Acquisition and allocation of funds are mostly what school heads are being minded of. More so, how those funds would be zeroed-in by thinking of expenditures, are mostly what school heads are after. Proper utilization, on the other hand, would be a better issue to be solved. Are the allocations of the acquired funds really helping in the delivery of learning and in advancing the cause of education? follows:

The seven themes constructed for implementing enhanced school learning continuity plan are as

5. Proper delivery and monitoring takes learning at its best.

6. Quality technical assistance can breed quality learning.

7. Activities become meaningful when resources are shared.

8. Pandemic calls for alternative arrangement to safeguard health.

9. Support is essential.

10. Make them feel at home, not just special.

11. Acquisition of fund is as important as proper utilization.

\subsection{Recommendations}

Based from the findings obtained in the conduct of this study, the following recommendations are now given to the following targeted persons or group of people:

- School heads should initiate projects that would handle the success of the institution in the seven dimensions of school learning continuity plan. The following projects are suggested:

- Focus on Learning - Project VACSIN (Validating Academic Compliance of Students through Interventions). This project which is particularly for modular distance learning revolves around the cycle of five interventions: (i) feedback given to learners and parents regarding the output submitted, (ii) weekly provision of resource materials through group chat, (iii) regular follow-up and encouragement to learners with regards to the production of their output, (iv) collaboration with parents through sending of pictures of learners studying and doing tasks at home, and (v) unlocking of difficulties through sending sample best output wherein learners can learn and relearn.

- Ensuring Quality of Teaching and Learning Process - Project CURES (Communicating, Uplifting 
and Restoring Errant Students). Students who are at risk of dropping out from school will be taken care through this project. Communication and restoration through provision of enhancement activities will be the two main elements of this project.

- Provision of Learning Resources - Project LEAD (Leaders for Emulation through Assistive Development). Coaching and mentoring of proficient teachers by the highly proficient teachers will be the focus of this project. Increased performance rating will be one of the outputs.

- Safe Operations - Project MOLI (Mentoring of Leaders through Innovations). Through online coaching and mentoring of the school head for the master teachers and school head, continuous improvement can be expected. The output can be strategies developed either in teaching or in supervision.

- Well-being and Protection - Project WELNESS (Webinars and Lectures for Nurturing Educational Safety and Soundness). Mainly initiated by the guidance counselor through the assistance of homeroom advisers, this project will seek to take care of the mental and psychosocial health of the learners and the community as well.

- Reaching the Marginalized - Project ALERTT (Alternative-learning-system LEarners and Returnees' Talents to be Tapped). ALS learners, returnees (Balik-Aral students), and even transferees will be given importance through this. Their skills will be enhanced, giving them the feeling that they are warmly welcome in the institution, and resulting to avoidance of drop-outs.

- Education Funding - Project STAKE (Stakeholders' Trust as Key Element to Success). This project will seek to tap community partners to uphold the cause of quality education for young minds. Preparation of school report card being distributed to targeted stakeholders and encouraging them to take part in putting into realization the school mission and vision will ensure commitment and healthy partnership.

- District and division head officials should continue in implementing projects that acknowledge and reward school heads' and personnel's effort in continuing to deliver quality education amidst pandemic and different community crises.

- Future researchers should venture into the aspect of community implication and impact of the school learning continuity plan being spearheaded by the school heads. This would be a good ground for evaluating the success of the school learning continuity plan within the school year of the institutions operation.

\section{References}

Albanese, Erin. (2014). "Dental Team Saving Teeth, School Days, in Districts High Need." School News Network: A Window into Your Public Schools, posted November 13, 2014. https://www.school- newsnetwork.org/2014/11/13/dental-team-savingteeth-school-days-districts-high-need/

Allen, Danielle, Lucas Stanczyk, Rajiv Sethi, and Glen Weyl. (2020). "When Can We Go Out? EvaluatingPolicy Paradigms for Responding to the COVID-19 Threat." Edmond J. Safra Center for Ethics, COVID-19 Rapid Response Impact Initiative, White Paper 2. https://ethics.harvard.edu/when-can-we-go-out

Alterator, Scott, Craig Deed, and Vaughan Prain. (2018). "Encapsulating Teacher Expertise in Action." Teachers and Teaching: Theory and Practice 24 (4): 450-60.

Ananat, Elizabeth O., and Anna Gassman-Pines. (2020). "Snapshot of the COVID Crisis Impact on Working Families." EconoFact. March 30, 2020. https://econofact.org/snapshot-of-the-covid-crisis-im- pact-on-working-families

Azorín, C. , A.Harris, and M.Jones . (2020). “Taking a Distributed Perspective on Leading Professional Learning Networks.” School Leadership \& Management 40 (2-3): 111-127. doi:10.1080/13632434.2019.1647418.[Taylor \& Francis Online], [Web of Science ®], [Google Scholar]

Baltag, Valentina, Anastasiya Pachyna, and Julia Hall. (2015). "Global Overview of School Health Services: Data from 102 Countries." Health Behavior and Policy Review 2 (4): 268-83. https://doi. org/10.14485/hbpr.2.4.4

Bauer, Lauren. (2020). "The COVID-19 Crisis Has Already Left too Many Children Hungry in America." Brookings, posted May 6, 2020. https://www.brookings.edu/blog/up-front/2020/05/06/the-covid-19-cri- sis-has-already-left-too-many-children-hungryin-america/

Buras, Kristen L. (2011). "Race, Charter Schools, and Conscious Capitalism: On the Spatial Politics of Whiteness as Property (and the Unconscionable Assault on Black New Orleans).” Harvard EducationalReview 81 (2): 296-331.

Cavanagh, Emily, and Eleanor Goldberg Fox. (2020). "Some Parents Say They're Not Homeschooling during the Coronavirus Pandemic Because It's Too Stressful.” Insider, March 25, 2020. https://www. insider.com/parents-wont-homeschool-in-coronavirus- 
pandemic-because-of-stress-2020-3

CLASP. (2015). "Course, Counselor, and Teacher Gaps: Addressing the College Readiness Challenge inHigh-Poverty High Schools." Center for Law and Social Policy, June 2015. https://www.clasp.org/sites/default/files/public/resources-and-publications/publication1/CollegeReadinessPaperFINALJune.pdf

Cresswell, JW. (2003) Research Design: Qualitative, Quantitative and Mixed Approaches ( $2^{\text {nd }}$ ed). Thousands Oaks, CA sage

DeParle, Jason. (2020). “Hunger Program's Slow Start Leaves Millions of Children Waiting." New York Times, May 26, 2020. https://www.nytimes.com/2020/05/26/us/politics/child-hunger-coronavirus.html

Dynarski, Susan. (2018). "Online Courses Are Harming the Students Who Nee the Most Help.” New York Times, January $19,2018$. https://www.nytimes.com/2018/01/19/business/online-courses-are- harming-the-students-who-need-the-most-help.html

Fetters, M. D. , and J. F.Molina-Azorin . (2020). "Call for Papers for a Special Issue on COVID-19 and Novel Mixed Methods Methodological Approaches During Catastrophic Social Changes.” Journal of Mixed Methods Research 14 (3): $281-287$. doi:10.1177/1558689820920098. [Crossref], [Web of Science ®], [Google Scholar]

Gagnon, Douglas J., and Marybeth J. Mattingly. (2016). "Most U.S. School Districts Have Low Ac- cess to School Counselors." Carsey Research, National Issue Brief \#108, Fall 2016. Universi- ty of New Hampshire, Carsey School of Public Policy. https://scholars.unh.edu/cgi/viewcontent. cgi?article=1285\&context=carsey

Goldstein, Dana. (2020). "Research Shows Students Falling Months Behind During Virus Disruptions.” New York Times, June 4, 2020 (updated June 10, 2020). https://www.nytimes.com/2020/06/05/us/cor-onavirus-education-lost-learning.html

Harris, Elizabeth A. (2020). “'It Was Just Too Much’: How Remote Learning Is Breaking Parents.” New York Times, April $27,2020$. https://www.nytimes.com/2020/04/27/nyregion/coronavirus-homeschool- ing-parents.html

Hargreaves, A. , and M.Fullan . (2020). "Professional Capital after the Pandemic:Revisiting And revising Classic Understandings of Teachers' Work." Journal of Professional Capital and Community ,https://www.emerald.com/insight/publication/issn/2056-9548\#earlycite [Crossref], [Web of Science $\left.{ }^{\circledR}\right]$, [Google Scholar]

Harris, A. (2020). "COVID-19 - School Leadership in Crisis?" Journal of Professional Capital and Community . https://www.emerald.com/insight/publication/issn/2056-9548\#earlycite [Crossref], [Web of Science ®], [Google Scholar]

Harris, A. , and M.Jones . (2012). “Connect to Learn: Learn to Connect.” ProfessionalDevelopment Today 14 (4): 13-19. [Google Scholar]

Hub Staff. (2019). “Setting Sights Higher: World Sight Day.” Johns Hopkins University, HUB, October 10, 2019. https://hub.jhu.edu/2019/10/10/vision-for-baltimore-sight-day/

Kelly, Mary Louise. (2020). “The Long-Term Effects of Months-Long School Closures on U.S. Children. Interview with Dr. John King Jr." NPR.org, April 24, 2020. https://www.npr.org/2020/04/24/844562989/ the-long-term-effects-of-months-long-schoolclosures-on-u-s-children

Kuhfeld, Megan, and Beth Tarasawa. (2020). "The COVID-19 Slide: What Summer Learning Loss Can Tell Us about the Potential Impact of School Closures on Student Academic Achievement." NorthwestEvaluation Association, Collaborative for Student Growth, Brief, April 2020. https://www.nwea.org/con-tent/uploads/2020/05/Collaborative-Brief_Covid19-Slide-APR20.pdf

Leithwood, K. , A.Harris, and D.Hopkins . (2020). "Seven Strong Claims about Successful School Leadership Revisited.” School Leadership \& Management $40(1)$ :

Litvinov, Amanda. (2020). "Nearly 2 Million Education Jobs Could Be Lost-Unless the U.S. Senate Acts." Education Votes, June 9, 2020. National Education Association. https://educationvotes.nea. org/2020/06/09/nearly-2-million-education-jobs-could-belost-unless-the-u-s-senate-acts/

Long, Heather. (2020). “U.S. Now Has 22 Million Unemployed, Wiping Out a Decade of Job Gains.” Washington Post, April 16, 2020. https://www.washingtonpost.com/business/2020/04/16/unemploy- ment-claims-coronavirus/

Malkus, Nat, and Cody Christensen. (2020). "School District Responses to the COVID-19 Pandemic: Round 4, Halfway Through Closures." American Enterprise Institute, May 2020. https://www.aei.org/ wp-content/uploads/2020/05/School-DistrictResponses-to-the-COVID-19-Pandemic-Round-4.pdf

Manjoo, Farhad. (2020). "Two Parents. Two Kids. Two Jobs. No Child Care." New York Times, April $22,2020$. https://www.nytimes.com/2020/04/22/opinion/coronavirus-parenting-burnout.html

Maughan, Erin D. (2018). “School Nurses: An Investment in Student Achievement.” Phi Delta Kappan 99(7): 8-14. https://kappanonline.org/maughan-school-nurses-investment-student-achievement/ McArdle, Elaine. 2019. "The Middle of Somewhere." Harvard Ed. (Summer): 26-29, 48. https://www.gse.harvard.edu/news/ed/19/05/middle-somewhere

McCarthy, E., Gibson, C., Andrews-Dyer, H., and Joyce, A. (2020). “A Working Mom's Quarantine Life.” Washington Post, May 6, 2020. https://www.washingtonpost.com/lifestyle/2020/05/06/coronavirus- pandemic-working-moms-quarantinelife/?arc404=true

Parcak, Sarah. (2020). @indyfromspace. Twitter post, April 8, 2020, 6:57 am. https://twitter.com/indyfromspace/status/1247856156963409920

Reardon, Sean F. (2011). "The Widening Academic Achievement Gap between the Rich and the Poor: New Evidence and Possible Explanations." In Whither Opportunity? Rising Inequality, Schools, and Children's Life Chances, edited by Greg J. Duncan and Richard J. Murnane. New York: Russell SageFoundation.

Patterson and Keheller (2005) Resilient School Leaders: Strategies for rninf Adversity Into Achievement” ISBN 978-1-4166-0267-5 Sen, Amartya. (2009). The Idea of Justice. Cambridge, MA: Harvard University Press.

Whitaker, Amir, Sylvia Torres-Guillén, Michelle Morton, Harold Jordan, Stefanie Coyle, Angela Mann, and Wei-Ling Sun. [2019]. Cops and No Counselors: How the Lack of School Mental Health Staff Is Harming Students. American Civil Liberties Union, March 4, 2019. https://www.aclu.org/sites/default/ files/field_document/030419-acluschooldisciplinereport.pdf 
Washburn, David. (2019). “Even When Districts Want More School Nurses, They Have Trouble Find- ing Them.” EdSource, February 24, 2019. https://edsource.org/2019/even-when-districts-want-more- school-nurses-they-have-trouble-finding-them/609022

Willgerodt,MayumiA.,Douglas M.Brock, andErinD.Maughan.2018). "PublicSchoolNursingPracticeintheUnited States.” Journal of School Nursing 34 (3): 232-44. 